\title{
対側副腎へ転移した腎細胞癌症例
}

$\begin{array}{cllll} & \text { 勝 } & \text { 岡 } & \text { 洋 } & \text { 治 } \\ \text { 東海大学医学部泌尿器科学教室 } & \text { 川 } & \text { 嶋 } & \text { 敏 } & \text { 文 } \\ \text { (主任:河村信夫教授) } & \text { 白 } & \text { 水 } & & \text { 幹 } \\ & \text { 村 上 } & \text { 上泰 } & \text { 秀* } \\ \text { *現清水市立清水総合病院 } & & \end{array}$

\section{CONTRALATERAL ADRENAL METASTASIS IN RENAL CELL CARCINOMA}

\author{
Yoji Katsuoka, Yasuhide Murakami, Toshifumi Kawashima and Miki Shiramizu \\ Department of Urology, Tokai University School of Medicine \\ (Director: Prof. N. Kawamura)
}

Approximately one third of patients discovered to have renal cell carcinoma already have distant metastasis at the time of tumor diagnosis. The commonest sites for metastasis are lungs, lymphnodes, and bones. Adrenal metastasis is a fairly common finding in autopsy series with a 7 to 19 per cent incidence reported. Nonetheless, the diagnosis of the metastasis to the adrenal is uncommon during life. In the literature, ipsilateral adrenal involvement has been previously reported to occur in $5.7 \%$ of all patients undergoing radical nephrectomy for renal cell carcinoma. In contrast, it seems suprising that metastatic renal cell carcinoma in the contralateral adrenal gland is not found more frequently. A case of a contralateral adrenal metastasis is here presented, and the literature is reviewed.

A 77-year-old man was admitted to a local hospital on October 1977, with urinary retention and gross hematuria. The patient was referred to our department, where extensive roentogenographic studies were performed. Results of arteriography and vena cavography demonstrated a large hypervascular mass in the upper pole of the kidney and tumor thrombus in the renal vein and vena cava consistent with a renal cell carcinoma. The patient underwent transcather embolization because of massive bleeding, thereafter a right radical nephrectomy and adrenalectomy including inferior vena cava wall resection. One year after discharge a CT scan disclosed a left suprarenal mass in the contralateral adrenal, suggestive of metastatic renal cell carcinoma. A left adrenalectomy was performed for treatment of the solitary metastatic lesion. Histologically, the tumor of the left adrenal was identical to the right renal cell carcinoma. The patient required adrenal cortical steroid (Hydrocortisone) and remained well over a two year follow-up interval.

\footnotetext{
要旨：腎細胞癌の対側副腎への孤立性転移症例を経験したので報告する.

患者は77歳の男性で尿閉と濃血尿を主訴に某市内病院に緊急入院した。尿路悪性腫瘍を疑われ精査目 的で当科へ転入した. 腹部および腎動脈撮影と下大静脈撮影にて静脈内腫瘍栓塞を有する右腎細胞癌が 判明した。撮影時に止血と腫㴼縮小を目的に transcatheter embolizationを行なった。その後右腎全摘 出術および右腎静脈の下大静脈内流入部を含む壁切除を施行した。退院後は外来にて定期的に諸検査が 行なわれ, 明らかな転移巣は認められなかったが, 術後約 1 年後に行なわれた CT scan で左副腎に一致 して腫瘍病変が発見され, 孤立性の転移性副腎腫瘍が強く疑われたので手術目的で再入院. 左副腎摘出 術が行なわれ, 摘出標本の病理組織学的診断では腎細胞癌と同一の所見であった. 副腎摘出後は八イド ロコーチゾンによる補充療法と非特異的免度賦活剤により 2 年以上転移もなく順調に経過した。
}

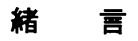

腎細胞癌の約 3 分の 1 は初診時すでに遠隔転移がみ
られると言われる。そして転移の好発部位は肺, リン パ節，骨などが代表的なものである．副腎への転移は 
剖検例では $7 \sim 19 \%$ の頻度にみられるものの, 生前に 発見されることは稀れである ${ }^{1) \sim 3)}$ 。腎細胞癌の発生し た腎と同側の副腎への転移は根治的腎全摘出術が行な われた患者の $5.7 \%$ にみらることが報告されている （4）．一方，対側副腎への孤立性転移として生前に診 断される機会は少なく, 内外の報告例をわずかに散見 する程度である。しかし, 近年の画像診断法の進歩に より転移の発見は比較的容易となってきた。

我々は腎静脈および下大静脈内腫瘍栓塞を伴った腎 細胞癌に対し, 腎全摘出術と下大静脈壁切除を施行し, その後外来通院にて経過観察中にCT scan で発見さ れた対側副腎への転移症例を経験したので若干の文献 的考察を加光て報告する。

\section{I. 症 例}

患者：持 $\bigcirc$ 六 $\bigcirc ，$ 男, 77 歳, \#493881

初診：昭和52年11月 8 日。

主訴：肉眼的血尿，尿閉。

家族歴：特記すべきことなし。

既往歴：胃潰瘍（内服治療にて治癒）。

現病歴：死亡するまで泌尿器科・内科に計 7 回の入 退院をくりかえしているが，本論文の要旨に関係があ ると思われる初回入院より 3 回までを略記する。

第 1 回目入院(昭和52年 11 月 8 日～同年 12 月 22 日)： 昭和 52 年 10 月 16 日, 突然尿閉となり某市内病院へ緊急 入院となった。膀胼洗浄にて多量の血塊の排出を認め, 膀胱血液タンポナーデの状態であったので尿路悪性腫 瘍が疑われ精査目的で当科へ転入した。入院後の膀脱 鏡検査にて血塊と共に粘膜の隆起性病変が疑われ，経 尿道的試験切除が行なわれたが壊死組織のみであっ た。その後動静脈の血管撮影により，下大静脈内腫瘍 栓塞を有する右腎細胞癌が判明したが濃血尿が持続し たため，止血と腫瘍縮小を目的で Transcatheter embolizationを行なった。肉眼的血尿消失した時点で腎 摘出術を予定したが本人の希望により一旦退院となっ た。

第 2 回目入院(昭和53年 1 月 21 日 3 月 7 日)： 2 月 7 日直ちに右腎全摘出術および下大静脈内への腫瘍栓 塞に対して腎静脈の下大静脈流入部を含む壁切除を施 行した。摘出標本の病理診断は透明細胞型で腎線維被 膜への浸潤，右副腎，周囲リンパ節への転移が認めら れた。

第 3 回目入院 (昭和 54 年 5 月 21 日 7 月 25 日)：術後 外来にて定期的に諸検査が行なわれ，胸部レントゲン， 骨や肝シンチグラムなどにも転移巣は認められなかっ
たが, 昭和54年 4 月26日に行なわれた CT scan で左副 腎に一致して腫瘍病変が発見され，孤立性の転移性副 腎腫崵が強く疑われ手術目的で入院となった。

初回入院時現症: 体格長身, 栄養中等度, 脈拍 $100 /$ $\mathrm{min}$, 不整, 血圧 $106 / 70 \mathrm{mmHg}$, 眼䀫結膜に貧血を認め た。聴診上心音はリズム不整でI 音は大小不揃いで あった。右上腹部に可動性を有する腫瘤を触知し，圧 痛を認めた。下肢に浮腫はなく，外性器にも異常を認 めなかった。

入院時検査成績: 末梢血所見: 白血球 $9.4 \times 10^{3} /$ $\mathrm{mm}^{3}$, 赤血球 $301 \times 10^{4} / \mathrm{mm}^{3}$, 血色素 $9.8 \mathrm{~g} / \mathrm{dl}$, へマトク リット $29.2 \%$, 白血球分画は正常，血小板 $22.8 \times 10^{4} /$ $\mathrm{mm}^{3}$, プロトロンビン時間 11.8 秒, フィブリノーゲン $670 \mathrm{mg} / \mathrm{dl}$, 血沈 $129 \mathrm{~mm}$ ( 1 時間値), 血液化学所見; A/ G 1.33, GOT 20U/I, GPT 18U/I, LDH 165U/I, CPK $51 \mathrm{U} / \mathrm{I}, \mathrm{AI}-\mathrm{phos} 65 \mathrm{U} / \mathrm{I}$, 総ビリルビン $0.6 \mathrm{mg} / \mathrm{dl}$, 直接 ビリルビン $0.3 \mathrm{mg} / \mathrm{dl}$, 総コレステロール $96 \mathrm{mg} / \mathrm{dl}$, ト リグリセライド $64 \mathrm{mg} / \mathrm{dl}$, TTT 3.3SHU, ZTT 8.4 KU, コリンェステラーゼ1,683U/I, LAP $27 \mathrm{U} / \mathrm{I}, \gamma$ GPT $20 \mathrm{U} / \mathrm{I}$, アミラーゼ71SR/dl, Fe $28 \mu \mathrm{g} / \mathrm{dl}, \mathrm{BUN}$ $25 \mathrm{mg} / \mathrm{dl}$, クレアチニン $1.9 \mathrm{mg} / \mathrm{dl}$, 尿酸 $6.2 \mathrm{mg} / \mathrm{dl}, \mathrm{Na}$ $138 \mathrm{mEq} / 1, \mathrm{~K} 4.6 \mathrm{mEq} / 1, \mathrm{Cl} 103 \mathrm{mEq} / 1, \mathrm{Ca} 4.3 \mathrm{mEq} / \mathrm{l}$, P $2.2 \mathrm{mEq} / \mathrm{l}$, 血糖 $102 \mathrm{mg} / \mathrm{dl}$, 血清蛋白分画; 総蛋白 $5.8 \mathrm{~g} / \mathrm{dl}$, アルブミン $53.2 \% ， \alpha_{1}$ グロブリン $6.0 \%, \alpha_{2}$ グ ロブリン $13.5 \%, \beta$ グロブリン $6.0 \%, \gamma$ グロブリン $21.4 \%$, IgG $1,250 \mathrm{mg} / \mathrm{dl}, \mathrm{IgA} 312 \mathrm{mg} / \mathrm{dl}, \mathrm{IgM} 201 \mathrm{mg} /$ $\mathrm{dl}, \mathrm{RA}$ テスト $(2+), \mathrm{CRP}(5+)$ 尿所見; 濃赤色, 比 重1,026, pH 6.0, 蛋白 (3+) ウロビリノーゲン $( \pm)$, 尿培養 serratia marcescens $10^{7} / \mathrm{ml}$, 便潜血 $(+)$, 腎 機能検查；PSP 12\% (15分値)，フィシュバーグ濃縮 試験 $1,006, \mathrm{GFR} 42.1 \mathrm{ml} / \mathrm{min}$, 尿細胞診 Class I II, 尿 中 CEA $26.5 \mathrm{mg} / \mathrm{dl}$, 血中 CEA $3.84 \mathrm{ng} / \mathrm{al}$, 心電図は心 房細動を示めし胸部レントゲン上軽度心肥大, DIP で は右腎の上極に腫瘍の存在と腎の下方への偏位がみら れた。 ${ }^{99 m}$ TC-DMSA 2mCi 静注による腎シンチグラム では腫瘤部分に一致して cold area を認めた。腹部大 動脈㐨上び巽択的腎動脈撮影は豊富な新生血管, A-V shunt, 造影剤の貯瘤像などの所見を示めし腎細胞癌と 診断された。さらに下大静脈撮影では血管内腔の一部 に陰影欠損像がみられ腫瘍栓塞の存在を疑わせた。肝 シンチグラム上異常は認められなかった。 以上，初回 入院時の検查成績である。第 2 回目入院では術前, 術 後に特記すべき異常值は認めなかった。第 3 回目入院 時の末梢血抢よび血液化学所見は注ぼ正常であった 
Fig. 1 (A) CT scan after contrast material reveales a $4 \mathrm{~cm}$ mass with necrosis between spleen and aorta. (B) CT scan at lower level again demonstrates round-shaped tissue density overlying left kidney.
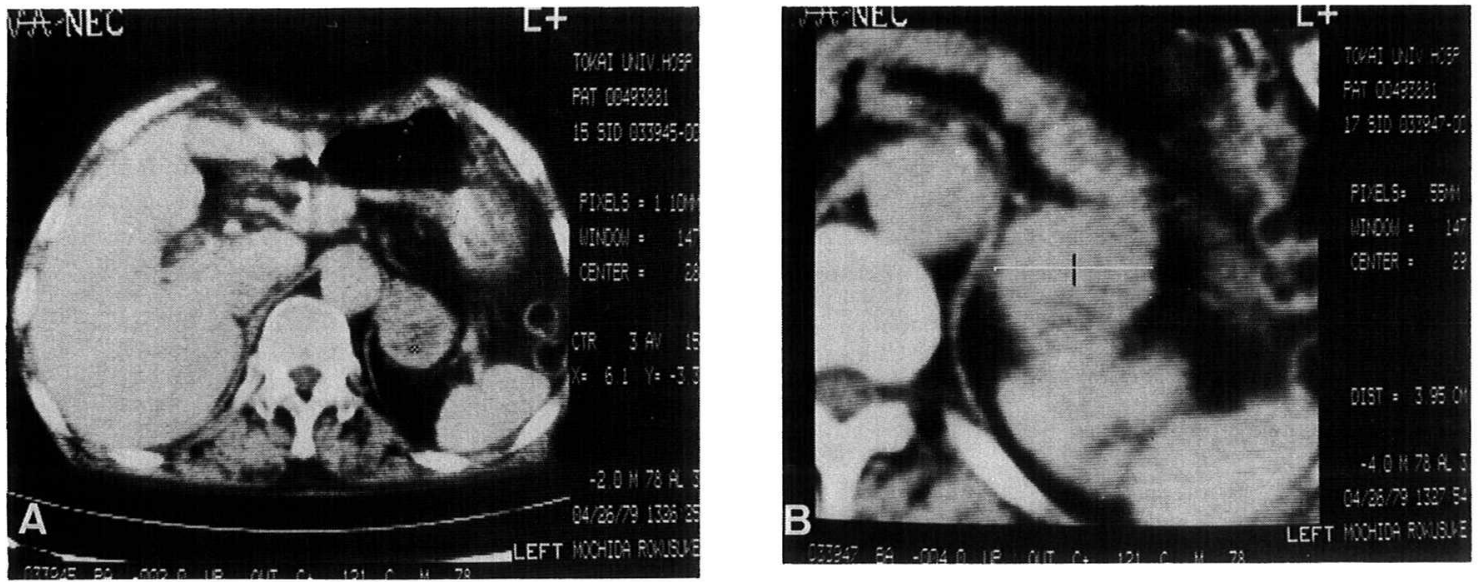

Fig. 2 (A) Abdominal aortogram reveales a hypervascular mass overlying left kidney (arrow). (B) Selective mid-adrenal angiogram shows encasement of arterial tree with neovascularity.

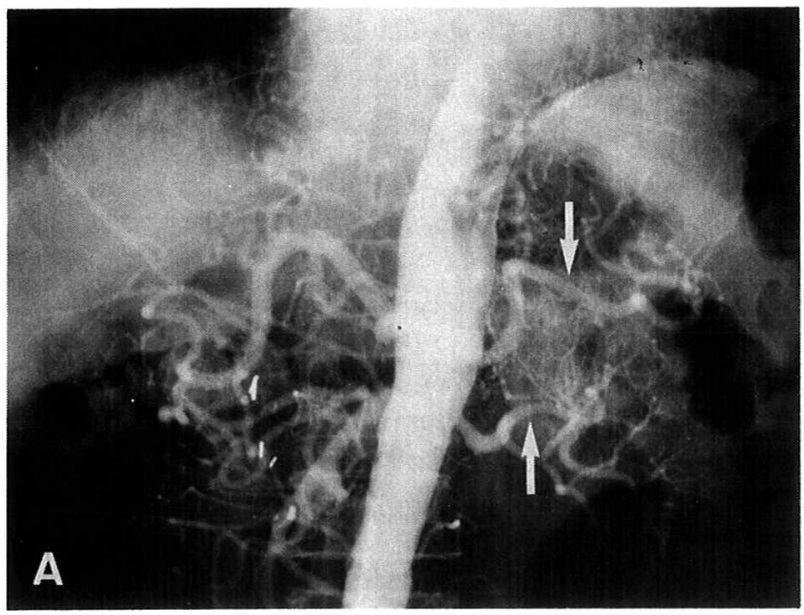

が，胸部レントゲンで左下肺野に渗出性病変が認めら れた. 肺機能検查では肺活量 $3.01 / \mathrm{L}$, 最大吸気量 2.29 / $\mathrm{L}$, 予備呼気量 $0.71 / \mathrm{L}$, 時間肺活量（1 秒率） $74.5 \%$, 予備換気量 $21.074 / \mathrm{min}$ であった。胃透視では非活動性 の潰瘍病変が存在した。な秥副腎機能検查は施行して いない.

CT scanの所見；左腎上部に腎との境界の不明瞭 な径約 $4 \mathrm{~cm}$ の腫瘤がみられる。腫瘤内の中心部には壊 死部分と思われる low density area が存在する。また 腎には多発性囊腫がみられた（図 1 )。

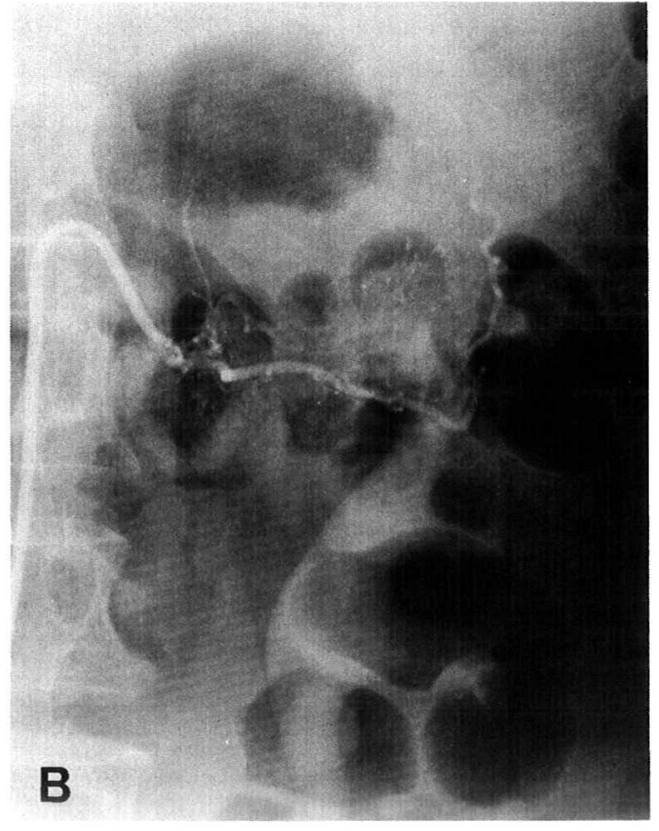

血管撮影の所見；腹部大動脈撮影では左腎上極より 副腎にかけて口径不整な血管と腫湯状濃染を認める. 選択的腎動脈撮影では腫瘍陰影を描出できなかった が，超選択的副腎動脈撮影により中副腎動脈が腫瘍の 主たる栄養血管で新生血管に富んだ腫瑒であることが 示めされた（図2）. 
Fig. 3 (A) Highly cellular tumor composed of small nests is compactly arranged beneath normal layer of adrenal gland (arrow). Partially, these tumor nests form cystic spaces containing blood. (B) Tumor, cells have ovoid, hyperchromatic nuclei with nucleoli, and abundant clear or eosinophilic cytoplasm along with thin fibrovascular stroma. Histologically, this tumor is identical to renal cell carcinoma. (Magnification, $\times 14, \times 195$, respectively).

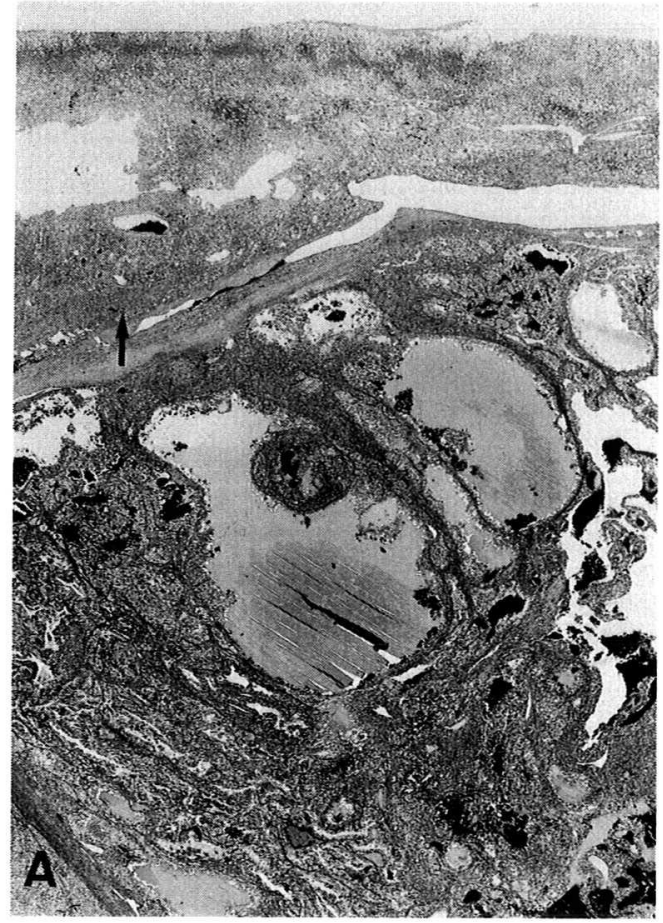

摘出標本の肉眼的所見と組織像；肉眼的には腫瘍は 被膜で囲まれ一部に正常副腎組織を残すのみであっ た。病理組織学的には腫瘍は小さな癌巣より形成され ており，クロマチンに富んだ核を有し，透明なあるい は好酸性の細胞質である。また癌巣は血液を含む囊胞 を形成している，以上の所見は腎細胞癌の組織学的特 徵であり，副腎への転移と判断された。な拈腫瘍によ り占拠されている部位が副腎の皮質が髄質かの区別は 明らかでない（図 3 ).

その後の経過；副腎摘出後はハイドロコーチゾンに よる補充療法と非特異的免疫賦活剂の投与に上り順調 に経過していたが, 2 年 6 カ月後に前腕骨に転移した。 局所の発赤, 腫脹, 疼痛が著明であったが対症的処置 により軽快した。当科外来受診の間にも心房細動，心 不全で内科併診しジギタリス療法を受けていたが，心 不全の增悪やジギタリス中毒により内科への入退院を くりかえした。この時期の度重なる胸部レントゲン撮

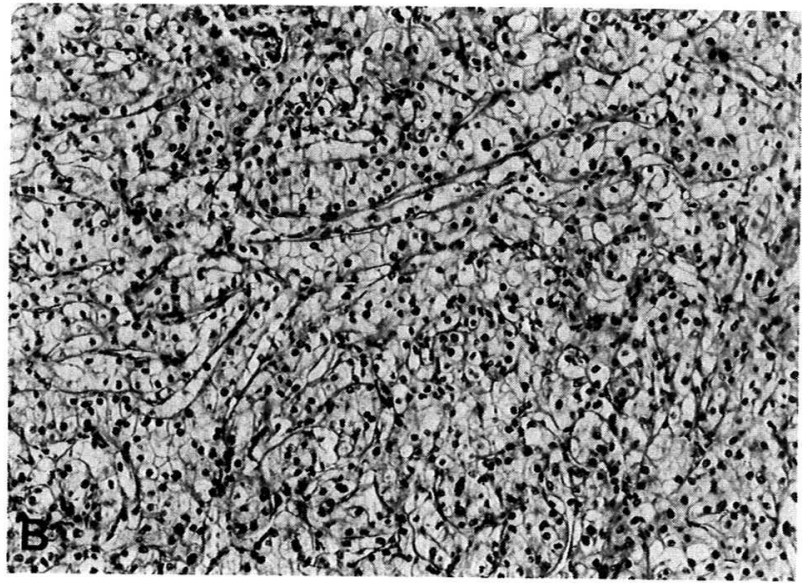

影にて多発性肺転移が発見された。その後も小康状態 を保っていたが昭和58年 6 月 25 日突然意識障害を生じ 内科へ緊急入院した。脳出血と心不全の悪化により, 7 月23日83歳で死亡した。剖検所見で肺，脳，後腹膜 に広汎な転移巣が認められた。

\section{II. 考 按}

腎細胞癌は一般的に悪性度の高い腫瘍と考光られ， 5 年生存率は 30 - $60 \%$ で詁る。予後不良である理由の 1 つに初診時すでに遠隔転移を有していることが上げ られる5)。さらに腎細胞癌が他の癌腫に比較して転移 し易いことが考兄られ，その原因となるべきいくつか の要因が想定される。

（1）腎細胞癌患者は比較的長期生存することがあ り，その間に転移の機会が増すこと。

（2）腎細胞癌細胞は特定の場所に運搬され易く，そ こで生存する傾向をもつこと。

（3）他の癌種では一般でない腎細胞癌に特有の転移 経路が存在すること。

（4）以上の要因が相互に関連した転移機構が存在す ることなどである。

Lucke \& Schlumberger ${ }^{6)}$ の剖検における調查では, 肺 $55 \%$ ，リンパ節 $38.1 \%$ ，肝 $35.0 \%$ ，骨 $33.1 \%$ ，副腎 $18.8 \%$, 胃 $7.5 \%$, 脳 $6.6 \%$, 脾 $5.3 \%$ ，心臓 $4.7 \%$ ，皮 膚 $3.1 \%$, 甲状腺 $1.3 \%$, 腸, 筋肉, 脊髄, 殬丸扔よび 精索, 膵蔵, 卵巣, 陰茎などは $1 \%$ 以下の頻度に転移 
がみられるとの結果を報告している，その後の Bennington \& $\operatorname{Kradzian}^{7)}$ による523例の剖検所見でも各 臟器別の転移部位の頻度はほぼ同じ成績である。本邦 では最近斉藤8)が1959年から1977年までの日本病理剖 検輯報に集録された腎細胞癌 1,451 例を分析し, 転移様 式について報告している。剖検所見にて転移が確認さ れた 1,293 例のうち, 単一臓器の転移が 120 例 ( $8 \%$ ), 2 つ以上の複数臟器への転移が残りの 1,173 例 (81\%) であった。複数臟器への転移を各臓器別の頻度でみる

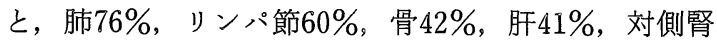
$23 \%$, 同側副腎 $17 \%$, 膵臓 $14 \%$, 胸膜 $12 \%$ 脳 $11 \%$, 対 側副腎 $11 \%$, 心藏 $11 \%$, 腹膜 $9 \%$, 腸 $9 \%$, 皮膚 $7 \%$, 横隔膜 $7 \%$ ，甲状腺 $5 \%$ ，後腹膜 $3 \%$, 膀胱 $2 \%$ ，尿 管 $1 \%$ の成績である。この中で副腎への転移に注目す るとその頻度は意外に多く，この他にも諸家の報告か

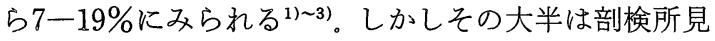
により得た成績であり, 生前に副腎への孤立性転移あ るいは複数臟器転移として発見される頻度について言 及した報告は見当らない。Wright ${ }^{2}$ は腎細胞癌の診断 のために選択的腎動脈撮影を施行した際に偶然に発見 された同側副腎への転移例を報告している。また Cambell ら ${ }^{3)}$ は同時期に発見された腎細胞癌と対側副 腎への転移と，同側副腎への転移の 2 例を報告してい る。腎細胞癌の対側副腎への転移の最初の臨床例は Foucar \& Dehner ${ }^{91}$ により発表された. かれらの経験 した 2 例のらち， 1 例は無機能性副腎皮質癌の術前診 断の下に開腹されており, 術後に対側の腎に腎細胞癌 を発見している。他の 1 例は腎上極に存在する腫瘤で 腎かあるいは副腎由来かの確証のない木をに開腹され 腎および副腎摘出が行なわれ, 組織学的には透明細胞 型の腎細胞癌で副腎への転移性腫瘍であることが確認 された。しかし原発巣については術前の CT scan で対 側腎に小腫瘤が認められているが患者が手術を拒否し ているため実証されていない。本邦では術前に同側あ るいは対側腎に転移が発見された症例として期波 $ら^{10)}$, 久住ら ${ }^{11}$, 峰山ら ${ }^{12)}$ の報告がある。最近では増田 $5^{13)}$ 三方ら ${ }^{14)}$ が，対側副腎転移の手術例を報告してお り, 本症例同様に腹部 CT scan で発見されており, 超 音波検査を含む画像診断法の有用性が裏付けられてい る.

ところで腎細胞癌の副腎への転移経路については興 味のあるところであるが, Cambell ら゙は転移性副腎 腫瘍への栄養血管が副腎動脈だけならば血行性あるい はリンパ行性転移と考えられ, 腎動脈と副腎動脈の両
方より供給を受けていれば副腎への直接浸潤によると の考光方を示している。ところで対側副腎への転移様 式は対側腎に転移が同時に存在しない限り血行性に癌 細胞が運搬された遠隔転移のはずである。一方, 斉藤 $ら^{15)}$ は年齢と腎細胞癌の転移様式を検討し, 血行転移 の頻度は加齢之は無関係であるのに反し, リンパ行性 転移は減少する傾向があることを報告している，この 中でかれらは転移藏器別に加齢との関連で 3 つ分類 している。加齢とともに転移の頻度が減少する diminishing type の中には統計された時のリンパ節，肝，鎤 骨リンパ節，甲状腺，ソ径リンパ節，卵巣などが属し， 増加傾向をるつ increasing type には肋骨が代表的で ある。特定の年齢にピークをもつ peaked type には肺 門リンパ節, 気管リンパ節, 対側腎, 同側副腎, 心臟, 脳などが上げられている。さらには年齢により変動の ない invariable type には肺, 骨, 後腹膜リンパ節に加 えて対側副腎がこの中に含まれる。

本症を以上の文献上の成績と照合すると，対側副腎 への転移経路は血行性であり, 死亡するまでの 5 年余 の間に対側副腎, 骨, 肺へと転移巣が拡大しているこ とから, invariable type であることが推定される。

Lange ら ${ }^{16)}$ は反対側の腎および副腎への腎細胞癌 の転移はその $80 \%$ が腎静脈や下大静脈内の腫瘍栓塞を 有していると報告して和り，本症はこの事象を立証す るものであるかも知れない。しかし斉藤 ${ }^{17)}$ は静脈内腫 瘍栓塞のみられる群では，肝，肝門リンパ節，尿管に 高い頻度で転移がみられる一方，骨，対側腎，脳では むしろ低くく，副腎については同側と対側とともに差 がない成績をまとめている。

一般的に転移性副腎腫瘍の原発巣としては肺癌やメ ラノーマに多く，転移部位は副腎皮質以上に髄質に多 いと言われているが，Addison 氏病の症状が発現する ことは非常に少ない18)。対側副腎に孤立性腫瘍として 発見された場合には原発性の無機能性副腎皮質腺腫や 副腎癌あるいは褐色細胞腫と続発性副腎腫瘍などとの 鑑別が困難であることが多い11).

今日の画像診断の進歩はめざすしく。生前に発見さ れることが難かしいと言わ机てきた副腎への転移，特 に対側副腎への転移の発見も容易になってきた。腎細 胞癌の対側副腎転移の頻度は諸家の報告より $15 \%$ 前後 みられること, その中には副腎単一臓器転移も存在す ることから外科的適応が生まれてくる可能性もあり, 転移の検索に当たり, 留意すべき点である。 


\section{III. 結 語}

膀脱血液タンポナーデを主訴とし, 腎静脈と下大静 脈内腫瘍栓塞を有した腎細胞癌に対し, Transcatheter embolization の後に腎全摘出術兼下大静脈壁切 除を施行し， 1 年 3 力月後に CT scan で発見された対 側副腎への孤立性転移例を報告した。㐬腎細胞癌の 副腎転移（同側および対側）の頻度と転移様式につい て言及した。

稿を終えるに当り, 終始適切な御助言と貴重な資料の提 供を賜った東海大学医学部移植学教室 I 斉藤 博助教授に 深甚なる謝意を表します。

\section{文献}

1) Hajdn, S.I. and Thomas, A.G.: Renal cell carcinoma at autopsy. J. Urol., 97, 978-982, 1967.

2) Wright, F.W.: Adrenal metstasees from renal carcinoma diagnosed by selective renal angiography. Br. J. Urol., 46, 472, 1974.

3) Campbell, C.M., Middleton, and Rigby, O.F.: Adrenal metastasis in renal cell carcinoma. Urology., 21(4), 403-405, 1983.

4) Robson, C.J., churchill, B.M. and Anderson, W.: The results of radical nephrectomy for renal cell carcinoma. J. Urol., 101, 297-301, 1969.

5) Middleton, R.G. : Surgery for metastatic renal cell carcinoma. J. Urol., 97, 973-977, 1967.

6) Lucke, B. and Schlumberger, H.G.: Tumors of the kidney, renal pelvis and ureter, in Atlas of tumor pathology, p. 43, A.E.I.P., Washington, D. C., 1957.

7) Bennington, J.L. and Beckwith, J.B.: Distribution of metastases from renal adenocarcinoma. In tumors of the kidney, renal pelvis, and ureter. p. 168, A.F.I.P., Washington, D.C., 1975.

8) Saitoh, H.: Distant metastasis of renal adenocarcinoma. Cancer 48(6), 1487-1491, 1981.

9) Foucar, E. and Dehner, L.P.: Renal cell carcinoma occurring with contralateral adrenalmetastasis. Arch. Surg., 114, 959-963, 1979.

10）期波光生，南 茂正，高村孝夫：対側副腎に巨大な 転移を示めした腎腫場. 臨床泌尿器科, 26, 369-370, 1972.

11）久住治男, 高野 学：両側副腎に比較的大きい転 移性腫瘍を伴った腎癌症例. 臨床泌尿器科, 34, 1105-1109, 1980.

12）峰山浩忠, 小松原秀一, 阿部札男：両側副腎飞転移 を示した腎細胞癌の 1 手術例。西日本泌尿器科, 43, 997-1001, 1981.

13）増田富士男, 大西哲郎, 東陽一郎, 池本 康, 町田 豊平: 腎細胞癌の対側副腎転移. 日本泌尿器科学 会誌, 74, 2138-2141， 1983.

14）三方律治，木下健二：孤立性対側副腎転移を来し た腎細胞癌の 1 例. 臨床泌尿器科, 38, 57-59, 1984.

15) Saitoh, N., Shiramizu, T. and Hida, M.: Age changes in metastatic patients in renal adenocarcinoma. Cancer, 50(8), 16460 1648, 1982.

16) Lang, E.K.: Angeriographic assessment and staging of renal cell carcinoma. Radiology, 101, 17-27, 1971.

17) Saitoh, H.: Distant metastasis of renal adenocarcinoma in patients with a tumor thrombus in the renal vein and/or vena cava. J. Urol., 127, 652-653, 1982.

18) Willis, R.A.: Secondary tumours of the adrenals. In the spread of tumours in the human body, 3rd, ed., p. 198, Butterworths \& Co, Ltd., London, 1973.

（1983年12月19日受付） 